Western University Scholarship@Western

Centre for the Study of International Economic Centre for the Study of International Economic

Relations Working Papers

Relations

1986

Liquidity, Banking, and Bank Failures

Stephen D. Williamson

Follow this and additional works at: https://ir.lib.uwo.ca/economicscsier_wp

Part of the Economics Commons

Citation of this paper:

Williamson, Stephen D.. "Liquidity, Banking, and Bank Failures." Centre for the Study of International Economic Relations Working Papers, 8608C. London, ON: Department of Economics, University of Western Ontario (1986). 
ISSN $0228-4235$

ISBN $\quad 0-7714-0725-4$

THE CENTRE FOR THE STUDY OF INTERNATIONAL ECONOMIC RELATIONS

WORKING PAPER NO. $8608 \mathrm{C}$

LIQUIDITY, BANKING, AND BANK FAILURES

Stephen D. Williamson

This paper contains preliminary findings from research work still in progress and should not be quoted without prior approval of the author.

DEPARTMENT OF ECONOMICS

THE UNIVERSITY OF WESTERN ONTARIO LONDON, CANADA

$\mathrm{N} 6 \mathrm{~A} \quad 5 \mathrm{C} 2$
Department of Economics Library

MAR 251986

University of Western Ontario 


\title{
LIQUIDITY, BANKING, AND BANK FAILURES
}

\author{
Stephen D. Williamson ${ }^{*}$ \\ Department of Economics \\ Queen's University \\ and \\ Department of Economics \\ University of Western Ontario \\ London, Ontario N6A $5 \mathrm{C} 2$ \\ Canada
}

Revised March, 1986

*Discussions with Scott Freeman, Zvi Hercowitz, Ignatius Horstmann and Peter Howitt were helpful in improving this paper. Financial support from the Social Sciences and Humanities Research Council of Canada is gratefully acknowledged. Any remaining errors are my own. 


\section{Abstract}

A model is constructed in which a liquidity problem arises in an equilibrium with decentralized trading in capital, which banking institutions are able to alleviate. Deposit contracts provide for early withdrawal, banks hold debt, and agents who borrow from banks hold compensating balances. The model is novel in that: 1) a role for banking arises in an environment where agents are risk neutral; 2) bank failures are systematic, tending to occur in states of the world where the demand for liquidity is high and output is low; 3) the possibility of bank failure does not imply a role for government intervention. 
1. Introduction

One view of the role played by banks is that they transform "illiquid" primary assets into "liquid" assets. Banks are able to profit from this transformation as some private agents, for one reason or another, prefer liquid bank liabilities to the primary assets which back them. While the provision of liquidity may be socially desirable, there is a widely-held belief, arising in part from American experience during the free banking era (1837-63), that unregulated banking systems are inherently unstable. ${ }^{1}$ Even $^{-6}$ some of the most strident supporters of laissez faire, including Friedman (1960), advocate regulations on banking activities to induce "stability". In this paper, a model is constructed in which banks bring about a liquidity transformation of assets and where bank failure is possible, yet there is no role for government intervention in the banking sector.

Formal models of banking and bank instability are relatively new. In studies by Diamond and Dybvig (1983), Haubrich and King (1983), Jacklin (1983, 1984), Smith (1984) and Waldo (1985), banking institutions play an insurance role when private agents face uncertain liquidity requirements. The models of Diamond and Dybvig and Waldo capture bank instability in the form of a "bad" equilibrium in which a bank "run" or "panic" occurs and production is interrupted. In these models, bank runs are random events which cause a fall in output below what it would be in a "good" equilibrium. Such models can be faulted on three counts. First, bank runs occur in part due to an exogenously-imposed sequential service constraint. Second, as Jacklin (1984) shows, the "good" equilibrium can be supported with decentralized securities trading, in which case runs cannot occur. Even in more general models of this type examined in Jacklin (1984), banking (i.e. demand deposit) contracts 
cannot improve on equity contracts in the absence of ad-hoc restrictions on demand deposit trading. Third, Gorton (1985) finds evidence that, at least during the National Banking era, U.S. banking "panics" were systematic events. In essence then, these models do not explain a special role for banking institutions, and since a bank run is a "sunspot" equilibrium, they do not provide a theory of bank failure.

In this paper, we construct a model in which primitive assets are illiquid, in the sense that buyers and sellers are asymmetrically informed concerning the future value of these assets. It would seem that the critical flaw in the Diamond-Dybvig type models is the absence of such an illiquidity problem, which in our model generates a role for banking when combined with a demand for liquidity by some consumers.

The model we construct shares several features with those of Diamond and Dybvig (1983), Freeman (1985), Jacklin (1983, 1984) and Smith (1984). The period structure is similar, a demand for liquidity results from agents' random preferences, and there exist primitive short-term and long-term assets. One important difference is that all agents are risk neutral, so that a role for banking does not arise due to the benefits from risk-sharing. Another difference is the approach we take to showing how decentralized markets and alternative ways of organizing trade may or may not support optimal allocations. This approach is similar to that in Boyd and Prescott (1985), though they work with a one-period framework which cannot address the issues related to banking and liquidity whitch we wish to examine. As in Boyd and Prescott, optimal allocations are essentially core allocations which satisfy incentive compatibility constraints. With decentralized trade in capital, an equilibrium may not exist or it: may be suboptimal, due to the 
possibility that those wishing to sell good quality capital may not be able to credibly distinguish themselves from those selling inferior capital. Banking institutions are able to obviate this illiquidity problem in that bank contracts support the optimal allocation in all states of the world. Essentially, banks internalize an externality.

A banking institution is a coalition of agents which maximizes the expected utility of its members by becoming large. The contracts written by these coalitions with their members are similar to real-world banking contracts in that deposit contracts provide for early withdrawal, the coalition holds debt, and agents who borrow from the bank also hold compensating balances.

Though banking coalitions can achieve an allocation which is strictly preferred to the capital market equilibrium allocation by all agents in some states of the world, in other states all agents are indifferent between the two allocations. Therefore, some banking coalitions may agree, ex ante, to dissolve in some states of the world and trade capital. These "bank failures" are possible only in states where, on average, output is low and the demand for liquidity is high. This is in accord with empirical evidence for the United States (see Bernanke 1983, Friedman and Schwartz 1963, and Gorton 1985), which shows that a high rate of bank failure tends to be associated with recession, a high currency-deposit ratio, and a large aggregate quantity of deposit withdrawals.

In our model, in states of the world where bank failures are observed, banks which remain in operation will be experiencing higher than average deposit withdrawals. Observing this state of affairs, we might call it a "banking panic", conclude that bank "runs" were causing banks to fail, and 
call for government intervention to prevent such "runs". However in this model, the fact that banks fail does not imply non-optimality, and no intervention is called for. Our results therefore differ from those of Diamond and Dybvig (1983), for example, in that bank failures are systematic events, and the existence of failures does not call for interventions in the form of government deposit insurance, lender-of-last-resort privileges, and the like. 2

The remainder of the paper is organized as follows. In Section 2, the model is constructed, and in section 3 an optimal allocation is defined and computed. In Section 4, it is shown that ex post trading of capital supports the optimal allocation in some states of the world, and that banking coalitions support an optimal allocation in all states. Bank failures are discussed in section 5. The final section is a summary and conclusion.

\section{The Model}

There are four periods, 0 through 3 . In period zero, a countable infinity of identical agents are born, and they may choose at this time to write contracts. In period one, each agent is endowed with one unit of capital and learns her type, $(i, j)$, where $i, j=1,2$.

Type $(1, j)$ agents die in period 2 , and their preferences are ordered according to $E\left(c_{2}\right)$, where $E$ is the expectation operator and $c_{i}$ is consumption in period i. A type $(2, j)$ agent dies in period three, and her preferences are ordered according to $E\left(c_{2}+c_{3}\right)$. Type $(2, j)$ agents have the ability to mimic type $(1, j)$ agents by "hiding" in period three.

A type $(i, j)$ agent is endowed with type $j$ capital. All capital is perfectly divisible and may be used in period one in one of two production 
processes. Production process 1 yields 1 unit of the period 2 consumption good for each unit of capital input in period 1, while process 2 yields a random return in period 3 . I.e., for each unit of type $j$ capital applied to process 2 in period 1 , output is $r_{1}$ units of the period 2 consumption good with probability $\pi_{j}$, and $r_{2}$ units with probability $1-\pi_{j}$. Returns are publicly observable. We have $r_{1}>r_{2}$ and $\pi_{1}>\pi_{2}$, and we assume that:

$$
\begin{aligned}
& \pi_{1} r_{1}+\left(1-\pi_{1}\right) r_{2}>1 \\
& \pi_{2} r_{1}+\left(1-\pi_{2}\right) r_{2}<1
\end{aligned}
$$

Inequalities (2.1) and (2.2) imply that, in autarky, a type $(2,1)$ agent will prefer process 2 production to process 1 production, while agents of types $(1,1),(1,2)$ and $(2,2)$ will prefer process 1 production to process 2 production.

The composition of the population is determined by a random variable $x=\left(x_{11}, x_{12}, x_{21}, x_{22}\right)$, where $x_{i j}$ is the fraction of type $(i, j)$ agents. We have $x_{i j}>0$ and $\sum_{i=1}^{2} \sum_{j=1}^{2} x_{i j}=1$. In period one, $x$ takes on a value $x$, which is known to all before trading occurs and before production decisions are made. In period zero, it is public knowledge that $x$ is distributed according to the probability distribution function $F(X)$.

This model shares several features with other models of banking and intermediation. As in Diamond and Dybvig (1983), Freeman (1985), Jacklin (1983, 1984), Smith (1984) and Waldo (1985), agents have random preferences and there exists a long-term and a short-term production technology. However, in contrast to Diamond and Dybvig, Jacklin, Smith, Waldo and Haubrich and King 
(1983), there exists no insurance role for banking here, as all agents are risk neutral and agents know their preferences before production decisions are made. Boyd and Prescott (1985) specify an environment with a countable infinity of risk neutral agents in which financial intermediation arises endogenously. However, theirs is a one-feriod model which cannot address the questions associated with liquidity and banking which we wish to examine here. Before indicating the sense in which our model captures the notion of illiquidity, it would be useful to precisely define "liquidity." A "fully liquid" asset is defined by Tobin (1965, Pg. 3) to be an asset which is "convertible without delay into currency at full market value". For our purposes, this definition is not very helpful. Implicitly, Tobin has told us that currency is liquid, without telling us what liquidity is. Also, if an asset is exchanged, in equilibrium it is exchanged for its market value, which cannot be anything less than "full". What we take Tobin to mean is that an asset is illiquid if the asset holder and potential buyers of the asset are asymetrically informed concerning its future value in exchange or consumption. If we could elicit agent's beliefs, there would clearly be "less" agreement among buyers and sellers of consumer durables than among buyers and sellers of currency, with respect to the future values of these assets.

In this sense, capital is an illiquid asset in our model. Agents who learn they are type $(1, j)$ in period 1 wish to consume in the next period, and they can do this either by using their capital to produce the period 2 consumption good, or by trading capital before making investment decisions. A type $(2, j)$ agent would be willing to exchange up to $\pi_{1} r_{1}+\left(1-\pi_{1}\right) r_{2}$ units of type 2 capital for type 1 capital. However, any agent offering more 
than one unit of type 2 capital for one unit of type 1 capital would have to contend with sellers of type 2 capital claiming their capital to be of type 1 . For a demand for liquidity to provide a role for banking institutions, it must be coupled with the existence of illiquid primary assets, as is the case here. In the models of Diamond and Dybvig (1983), Jacklin (1983, 1984), Smith (1984) and waldo (1985), there is a demand for liquidity, but primary assets are not illiquid in the sense we have defined it. As Jacklin (1983) has shown, in Diamond and Dybvig's model the "good" allocation can be supported by a market for shares. ${ }^{3}$ Even in the generalized versions of the Diamond and Dybvig model in Jacklin (1983, 1984), the superiority of demand deposit contracts over equity contracts depends on exogenously imposed trading restrictions on demand deposits.

\section{Optimal Allocations}

Our optimal allocations are similar to "equilibrium allocations" in Boyd and Prescott (1985), with some differences due to the different structure of our model. We invoke the revelation principle (see Harris and Townsend 1981), and restrict attention to allocations in which it is in each agent's interest to reveal her type in period 1 . Variables are defined as follows:

$c_{i j}^{2} \equiv$ consumption in period 2 by an agent of type $(i, j)$.

$c_{i j}^{3} \equiv$ consumption in period 3 by an agent of type $(i, j)$ not contingent on the return on the agent's capital if any of this capital was allocated to process 2 production.

$c_{i j k} \equiv$ consumption in period 3 by an agent of type $(i, j)$ if the return on the agent's capital allocated to process 2 production is $\mathbf{r}_{\mathbf{k}}$.

$z_{i j} \equiv$ proportion of the capital endowment of a type $(i, j)$ agent which is allocated to process 1 production in period 1 . 
The optimality criterion we will use is the expected utility of a representative agent in period zero. Since all agents are identical at this date, the probability of an agent becoming type $(i, j)$ in period one is $x_{i j}$. We let $u_{i j}$ denote the expected utility of a type $(i, j)$ agent conditional on information available in period one.

$$
u_{i j}=\left\{\begin{array}{l}
c_{i j}^{2}, i=1 \\
c_{i j}^{2}+c_{i j}^{3}+\pi_{j i j 1}+\left(1-\pi_{j}\right) c_{i j 2}, i=2
\end{array}\right.
$$

Therefore, a social planner will seek to maximize:

$$
E\left[\sum_{i=1}^{2} \sum_{j=1}^{2} x_{i j}{ }_{i j}\right]
$$

The expectation in (3.2) is taken with respect to $x$. Note that:

$$
\text { If } z_{i j}=1 \text {, then } c_{i j k}=0, i, j, k=1,2
$$

Resource constraints for periods two and three respectively, are:

$$
\begin{aligned}
& \sum_{i=1}^{2} \sum_{j=1}^{2} x_{i j}\left(c_{i j}^{2}-z_{i j}\right) \leq 0 \\
& \sum_{i=1}^{2} \sum_{j=1}^{2} x_{i j}\left[c_{i j}^{3}+\pi c_{i j 1}+(1-\pi) E_{j j 2}\right] \\
& \leq\left[\pi_{1} r_{1}+\left(1-\pi_{1}\right) r_{2}\right] \sum_{i=1}^{2} x_{i 1}\left(1-z_{i 1}\right) \\
& +\left[\pi_{2} r_{1}+\left(1-\pi_{2}\right) r_{2}\right] \underset{i=1}{2} x_{i 2}\left(1-z_{j .2}\right)
\end{aligned}
$$

We must also have:

$$
z_{i j} \leq 1, i, j=1,2
$$

Let $v_{i j}(k, l)$ denote the expected utility in period one of a type $(i, j)$ agent who claims to be type $(k, l)$. We have $v_{i j}(i, j)=u_{i j}$. For agents to truthfully report $(i, j)$, the following incentive compatibility conditions must be satisfied. We assume that if agents are indifferent, they report the 
truth.

$$
u_{i j} \geq v_{i j}(k, l), \quad(k, l) \neq(i, j)
$$

In addition, agents must prefer their allocation to what they could achieve under autarky:

$$
\begin{aligned}
& u_{i j} \geq 1,(i, j)=(1,1),(1,2),(2,2) \\
& u_{21} \geq \pi_{1} r_{1}+\left(1-\pi_{1}\right) r_{2}
\end{aligned}
$$

Note that under autarky, type $(1,1),(1,2)$ and $(2,2)$ agents choose to utilize the process 1 production technology and consume in period 2. Type $(2,1)$ agents utilize the process 2 technology and consume in period 3 .

Let $c$ denote the vector of $c_{i j}^{k}$ 's and $c_{i j k}$ 's and let $z=\left(z_{11}, z_{12}, z_{21}\right.$ ' $\left.z_{22}\right)$.

Definition 3.1. An optimal allocation, $\left(c^{0}, z^{0}\right)$, maximizes (3.2) subject to the resource constraints $(3.4)$ and (3.5), the constraints ( 3.1$),(3.3)$ and $(3.6)$, and the incentive constraints (3.7)-(3.9). In addition, if $\left(c^{0}, z^{0}\right)$ is an optimal allocation, there exists no subset of agents in period 1, with population parameter vector $x^{d}$, which can achieve a different allocation $\left(c^{d}, z^{d}\right)$ which satisfies:

$$
\begin{aligned}
& u_{i j}^{d}>u_{i j}^{0} \text { for some }(i, j) \\
& \text { If } u_{i j}^{d}<u_{i j}^{0} \text { then } x_{i j}^{d}=0 \\
& \text { If } u_{i j}^{d}>u_{i j}^{0} \text { then } x_{i j}^{d} \geq x_{i j} \\
& \text { If } u_{i j}^{d}=u_{i j}^{0} \text { then } x_{i j}^{d} \leq x_{i j}
\end{aligned}
$$




$$
\text { If } u_{i j}^{d}>u_{i j}^{0} \text { and } u_{k l}^{d}>u_{k l}^{0} \text {, then } x_{i j}^{d} / x_{k l}^{d}=x_{i j} / x_{k l}
$$

Resource constraints:

$$
\begin{aligned}
& \sum_{i=1}^{2} \sum_{j=1}^{2} x_{i j}^{d}\left(c_{i j}^{2 d}-z_{i j}^{d}\right) \leq 0 \\
& \sum_{i=1}^{2} \sum_{j=1}^{2} x_{i j}^{d}\left[c_{i j}^{3 d}+\pi_{j} c_{i j 1}^{d}+\left(1-\pi_{j}\right) c_{i j 2}^{d}\right] \\
& \leq\left[\pi_{1} r_{1}+\left(1-\pi_{1}\right) r_{2}\right] \sum_{i=1}^{2} x_{i 1}^{d}\left(1-z_{i 1}^{d}\right) \\
& \left.+\left[\pi_{2} r 2+\left(1-\pi_{2}\right) r_{2}\right] \sum_{i=1}^{2} x_{i 2}^{d}{ }^{(1-z}{ }_{i 2}^{d}\right)
\end{aligned}
$$

Incentive constraints:

$$
\begin{aligned}
& \underbrace{d}_{i j} \geq v_{i j}^{d}(k, l), \quad i, j \neq(k, l) \\
& u_{i j}^{d} \geq 1, \quad(i, j)=(1,1),(1,2),(2,2) \\
& u_{21}^{d} \geq \pi_{11} r_{1}+\left(1-\pi_{1}\right) r_{2}
\end{aligned}
$$

other constraints:

$$
x_{i j}^{d} \leq 1, \quad i, j=1,2
$$

A "d" superscript is used to denote a variable for the deviant coalition, defined as is the corresponding non-superscripted variable for the coalition of the whole.

The optimal allocation is contingent on the state of the world, $X$. Given $X=x$, it is in each agent's intere:st to truthfully report her type, and no coalition of agents can obtain a strictly preferred allocation. Deviant coalitions are composed of agents who weaikly prefer the allocation proposed 
by the deviant coalition to the candidate optimal allocation. Agents who strictly prefer the deviant allocation are drawn to the deviant coalition in the same relative proportions as they exist in the population.

The above definition of an optimal allocation is quite similar to Boyd and Prescott's (1985) definition of an "equilibrium allocation," though we use an ex ante welfare criterion, in that expected utility is maximized as of period zero, before agents learn their types. We also use a somewhat different definition of a deviant coalition. ${ }^{4}$

To compute optimal allocations, we choose $(c, z)$ to maximize (3.2) subject to (3.1) and (3.3) - (3.9), and the constraint that there exist no deviant coalition. To simplify this problem, first note that we can remove the expectation operator from (3.2). Then, choosing $(c, z)$ to maximize (3.2) subject to (3.1) and (3.3) - (3.9) is a linear programming problem, solutions to which we call incentive-efficient (IE) allocations. If any IE allocations are immune from deviant coalitions then these are optimal allocations, and we are done.

To compute the IE allocations, first note that the resource constraints (3.4) and (3.5) must be binding, since otherwise the value of the objective function could be increased without violating any of the constraints. Given this, we must have $c_{i j}^{3}=c_{i j k}=0$ for $i=1$ and $j, k=1,2$, since otherwise we could increase the value of the objective function while introducing slack into the constraints ( 3.7$)$. I.e. we should not allocate consumption to dead agents. Since having $c_{i j k}>0$ for $i=2$ may help with respect to incentive constraints, if $z_{11}<1$ then $z_{21}<1$ and if $z_{12}<1$ then $z_{22}<1$. I.e., if capital of type $j$ is to be allocated to process 1 production, we allocate the capital of type $(1, j)$ agents first. Note also that (3.1) and (3.7) imply 
that $c_{11}^{2}=c_{12}^{2}$ and $u_{11}=u_{12}$.

Define two new variables:

$$
Y_{i}=x_{1 i} z_{1 i}+x_{2 i} z_{2 i}
$$

Also, let $U(X)$ denote the maximized value of (3.2) (absent the expectation operator) subject to $(3.1)$ and $(3.3)-(3.9)$.

Proposition 3.1. The IE allocations are:

If $X_{11} \leq X_{22}$, then $Y_{1}=0, Y_{2}=X_{12}+X_{22} \cdot U(X)=X_{12}+X_{22}+\left[X_{11}+X_{21}\right]$ $\left[\pi_{1} r_{1}+\left(1-\pi_{1}\right) r_{2}\right], c_{221}=c_{222}=0$. For this case, the solution for $c_{11}^{2}, c_{21}^{2}$, $c_{22}^{2}, c_{21}^{3}, c_{22}^{3}, c_{121}$, and $c_{122}$ is not unique. If $x_{11} \geq x_{22}$ then $x_{1}=x_{11}-$ $X_{22}, Y_{2}=X_{12}+X_{22}, c_{11}^{2}=1, c_{21}^{2}=c_{22}^{2}=c_{221}=c_{222}=0$ and $U(X)=X_{11}+X_{12}$ $+\left(x_{21}+x_{22}\right)\left[\pi_{1} r_{1}+\left(1-\pi_{1}\right) r_{2}\right]$. Here, the solution for $c_{21}^{3}, c_{22}^{3}, c_{211}$ and $c_{212}$ is not unique.

Proof: Substituting using (3.4) and (3.5), (note that these are satisfied with equality), the objective function can be rewritten as: $\left[x_{11}+X_{21}\right]\left[\pi_{1} r_{1}\right.$ $\left.+\left(1-\pi_{1}\right) r_{2}\right]+\left[X_{12}+X_{22}\right]\left[\pi_{1} r_{1}+\left(1-\pi_{2}\right) r_{2}\right]+Y_{1}\left[1-\pi_{1} r_{1}-\left(1-\pi_{1}\right) r_{2}\right]+Y_{2}\left[1-\pi_{2} r_{2}\right.$ $\left.-\left(1-\pi_{2}\right) r_{2}\right]$. Therefore, given (2.1) and (2.2), if we were constrained only by (3.6) then the objective function would be maximized by setting $Y_{1}=0$ and $Y_{2}$ $=\mathrm{x}_{12}+\mathrm{x}_{22}$. If $\mathrm{x}_{11}>\mathrm{x}_{22}$, then this cannot be a solution since in this case (3.8) implies that (3.4) is not satisfied. However, in the case where $x_{11} \leq$ $x_{22}$, one solution, given that (3.3) implies $c_{221}=c_{222}=0$ is $c_{11}^{2}=1, c_{21}^{2}=$ $c_{21}^{3}=c_{212}=0, c_{211}=\left[\pi_{1} r_{1}+\left(1-\pi_{2}\right) r_{2}\right] / \pi_{1}, c_{22}^{3}=\left(x_{11} / x_{22}\right)\left[\pi_{1} r_{1}+\left(1-\pi_{1}\right) r_{2}\right]$, and $c_{22}^{2}=\left[x_{22}-x_{11}\right] / x_{22}$. This allocation is not unique as we could, say, increase $c_{211}$ by some $\varepsilon>0$ and decrease $c_{22}^{3}$ by $x_{21} \pi_{1} \varepsilon / x_{22}$. For sufficiently small $\varepsilon$, this will not violate any constraints. 
In the case where $x_{11}>x_{22}$, if we were to maximize the objective function subject to $(3.4),(3.5)$ and (3.8), ignoring the other constraints, we would set $Y_{1}=X_{11}-X_{22}$ and $Y_{2}=X_{12}+X_{22}$. This implies $c_{11}^{2}=1$, and $c_{21}^{2}=$ $c_{22}^{2}=c_{221}=c_{222}=0$. It remains to determine $c_{22}^{3}, c_{211}$ and $c_{212}$. One solution is $c_{212}=0, c_{22}^{3}=\pi_{1} r_{1}+\left(1-\pi_{1}\right) r_{2}$ and $c_{211}=\left[\pi_{1} r_{1}+\left(1-\pi_{1}\right) r_{2}\right] / \pi_{1}$. This is not a unique solution, as we could increase $c_{211}$ by $\varepsilon>0$, decrease $c_{22}^{2}$ by $x_{21} \pi_{1} \varepsilon / x_{22}$ and, for sufficiently small $\varepsilon$, not violate any constraints. Q.E.D.

If agents could precomit in period zero and if each agent's type were public information, the "first best optimum" which a central planner could achieve would involve setting $Y_{1}=0$ and $Y_{2}=X_{12}+X_{22}$. We would then have $U(X)=x_{12}+x_{22}+\left(x_{11}+x_{21}\right)\left[\pi_{1} r_{1}+\left(1-\pi_{1}\right) r_{2}\right]$ for all $x$. For the case $x_{11}$ $\leq \mathrm{X}_{22}$, the IE allocations are first best. However, in the case $\mathrm{X}_{11}>\mathrm{x}_{22}$ ' even if all type 2 capital is allocated to process 1 production, this is insufficient to make all type $(1, j)$ agents as well off as they would be in autarky, and some type 1 capital must be allocated to process 1 production.

Proposition 3.2. The set of optimal allocations is the subset of IE allocations for which $u_{21}=\pi_{1} r_{1}+\left(1-\pi_{1}\right) r_{2}, u_{11}=u_{12}=1$, and

$$
u_{22}=\left\{\begin{array}{l}
1-x_{11} / x_{22}+\left(x_{11} / x_{22}\right)\left[\pi_{1} r_{1}+\left(1-\pi_{1}\right) r_{2}\right], x_{11} \leq x_{22} \\
\pi_{1} r_{1}+\left(1-\pi_{1}\right) r_{2}, x_{11} \geq x_{22} .
\end{array}\right.
$$

Proof: Consider first the case where $x_{11} \leq x_{22}$, and consider as a candidate optimal allocation a (*) allocation which is IE and where $u_{21}>\pi_{1} r_{1}+$ $\left(1-\pi_{1}\right) r_{2}$. Then there is a deviant coalition which can propose an allocation such that $x_{11}^{d}=x_{11} /\left(1-x_{21}\right), x_{12}^{d}=x_{12} /\left(1-x_{21}\right), x_{21}^{d}=0$, and $x_{22}^{d}=$ 
$x_{22} /\left(1-x_{21}\right)$. One such allocation is: $c_{211}^{d}=\left[\pi_{1} r_{1}+\left(1-\pi_{1}\right) r_{2}\right] / \pi_{1}, c_{21}^{2 d}=c_{22}^{2 *}$ $+\left[x_{21} / x_{22}\right] c_{21}^{2 *}, c_{22}^{3 d}=\left[x_{11} / x_{22}\right]\left[\pi_{1} r_{1}+\left(1-\pi_{1}\right) r_{2}\right], z_{11}^{d}=0, z_{12}^{d}=z_{22}^{d}=1$. Replacing " 0 " by "*" in (3.10) - (3.20), (3.10) - (3.20) are satisfied, so that (*) allocations are not optimal allocations in this case.

For the case $x_{11} \geq x_{22}$, again consider a $(*)$ allocation as a candidate optimal allocation. Then there is a deviant coalition which can propose an allocation such that $x_{11}^{d}=x_{11} /\left(1-x_{21}\right), x_{-12}^{d}=x_{12} /\left(1-x_{21}\right), x_{21}^{d}=0$, and $x_{22}^{d}=$ $x_{22} /\left(1-x_{21}\right)$. One such allocation is: $c_{2: l 1}^{d}=\left[\pi_{1} r_{1}+\left(1-\pi_{1}\right) r_{2}\right] / \pi_{1}, c_{21}^{2 d}=c_{222}^{d}$ $=c_{22}^{2 d}=0, c_{11}^{2 d}=c_{12}^{2 d}=1, c_{22}^{3 d}=\pi_{1} r_{1}+\left(1-\pi_{1}\right) r_{2}, z_{11}^{d}=x_{11}-x_{22}, z_{12}^{d}=z_{22}^{d}=$ 1. Replacing " 0 " by "*", (3.10) - (3.20) are satisfied, which implies that the (*) allocations are not optimal allocations in this case as well.

We then need only consider as candiclate optima those IE allocations for which $u_{21}=\pi_{1} r_{1}+\left(1-\pi_{1}\right) r_{2}$. We will first examine the subset of such allocations for which $u_{11}\left(=u_{12}\right)>1$, and call these $(* *)$ allocations. Since IE allocations have the property $u_{11}=1$ for $x_{11} \geq x_{22}$, we need only consider the case $x_{11}<x_{22}$. Here, for any (**) allocation, there exists a deviant coalition which can propose an allocation such that $x_{11}^{d}=x_{11} /\left(1-x_{12}\right), x_{12}^{d}=$ $0, x_{21}^{d}=x_{21} /\left(1-x_{12}\right)$, and $x_{22}^{d}=x_{22} /\left(1-x_{12}\right)$. One such allocation is $c_{12}^{d}=c_{11}^{d}$ $=c_{11}^{* *}, c_{211}^{d}=\left[\pi_{1} r_{1}+\left(1-\pi_{1}\right) r_{2}\right] / \pi_{1}, c_{22}^{3 d}=\left(x_{11} / x_{22}\right)\left[\pi_{1} r_{1}+\left(1-\pi_{1}\right) r_{2}, c_{21}^{2 d}=\right.$ $c_{212}^{d}=c_{21}^{3 d}=0$ and $c_{22}^{2 d}=c_{22}^{2 * *}+\left(x_{12} / x_{22}\right)\left(c_{12}^{2 * *}-1\right)$. This allocation satisfies (3.10) $-(3.20)$, and the $(* *)$ allocation is therefore not optimal.

Now we can confine our attention to "o" allocations, which are IE and where $u_{21}=\pi_{1} r_{1}+\left(1-\pi_{1}\right) r_{2}$ and $u_{11}=u_{12}=1$, which implies given proposition 3.1 :

$$
u_{22}=\left\{\begin{array}{l}
1-x_{11} / x_{22}+\left(x_{11} / x_{22}\right)\left[\pi_{1} r_{1}+\left(1-\pi_{1}\right) r_{2}\right], x_{11} \leq x_{22} \\
\pi_{1} r_{1}+\left(1-\pi_{1}\right) r_{2}, x_{11} \geq x_{22} .
\end{array}\right.
$$


Since with an IE allocation each agent is as well off as in autarky, there exist no deviant coalitions with only one type of agent. Coalitions containing only the following types of agents can give their members levels of expected utility no greater than in autarky: a) $(1,1)$ and $(1,2)$; b) $(1,1)$ and $(2,1) ; c)(1,2)$ and $(2,2) ; d)(1,2)$ and $(2,1) ; e)(2,1)$ and $(2,2) ; f)(1,1)$, and $(1,2)$ and $(2,1) ; g(1,2),(2,1)$ and $(2,2)$. This follows from the incentive constraints $(3.17)-(3.19)$, and $(3.7),(3.8)$ and (3.9) then imply that ( 3.10$)$ cannot be satisfied for any of these coalitions. The only remaining possible types of deviant coalitions to consider are those containing only the following types of agents: 1$)(1,1)$ and $(2,2) ; 2)(1,1)$, $(2,1)$ and $(2,2) ; 3)(1,1),(1,2)$ and $(2,2) ; 4)(1,1),(1,2),(2,1)$ and $(2,2)$. None of these possible types of deviant coalitions can satisfy (3.10)(3.16). Therefore, "o" allocations are optimal. Q.E.D.

It follows from proposition 3.2 that, optimally, all gains from trade go to type $(2,2)$ agents. There can be no gains from trading with agents of type $(2,1)$ or type $(1,2)$, and since incentive compatibility implies that $u_{11}=u_{12}$, agents of types $(1,1),(1,2)$ and $(2,1)$ are indifferent between optimal allocations and autarky.

\section{Supporting Optimal Allocations: Capital Markets and Banking}

At this stage we wish to examine the market structures and institutions which will support optimal allocations. In particular, we want to show that assets are illiquid, at least in some states of the world, in the sense that agents do not always reveal the true characteristics of their capital endowments in equilibrium on a decentralized capital market. "Banking" 
institutions are capable of transforming illiquid assets into liquid assets, and thus obviate this problem.

\section{Capital Market Equilibrium}

The first arrangement we look at is decentralized trade in capital. Capital markets open in period 1 and involve exchanges of (alleged) type 1 capital for type 2 capital. Trading occurs before investment decisions are made. We assume that if agents are indifferent concerning revelation of their capital endowment type, that they tell the truth. Let $p$ denote the price of type 1 capital in terms of type 2 capital, and let $p^{*}$ denote the equilibrium price.

Proposition 4.1 If $x_{11} \geq x_{22}$, then $p^{*}=1$ and the capital market equilibrium allocation is optimal.

Proof: Suppose $x_{11} \geq x_{22}$. If $p<1$, the supply of type 1 capital is zero and the demand is positive. If $p>1$, all type $(1, j)$ agents will supply alleged type 1 capital and the demand for type 1 capital is no greater than $x_{22}$. Therefore, there is an excess supply of type 1 capital no smaller than $x_{11}+$ $x_{12}-x_{22}>0$. For $p=1$, type $(1,2)$ agents will allocate their capital to process 1 production and will consume the proceeds, while type $(2,1)$ agents will allocate their capital to process 2 production and will consume in period 3. Type $(1,1)$ agents are indifferent between autarky and selling capital, while type $(2,2)$ agents prefer to sell their type 2 capital and buy capital supplied by type $(1,1)$ agents. In equilibrium, a fraction $x_{22} / x_{11}$ of the capital endowment of type $(1,1)$ agents is sold and the remaining fraction is retained by type $(1,1)$ agents. All capital owned by type $(1,1)$ agents after trading is allocated to process 1 production. We therefore have $u_{11}=u_{12}$. 
$=1, u_{22}=\pi_{1} r_{1}+\left(1-\pi_{1}\right) r_{2}$ and $u_{21}=\pi_{1} r_{1}+\left(1-\pi_{1}\right) r_{2}$. Given proposition 3.2, this is an optimal allocation. Q.E.D.

Proposition 4.2 If $x_{11}<x_{22}$ and a capital market equilibrium exists, it is not optimal.

Proof: Suppose $x_{11}<x_{22}$. Then if $p<1$, the supply of type 1 capital is zero and the demand is positive, so we cannot have $p^{*}<1$. For $p=1$, type $(I, 1)$ agents are indifferent between selling type 1 capital and autarky, while type $(2,2)$ agents wish to exchange their endowment for type 1 capital. There is therefore an excess demand for type 1 capital of $x_{22}-x_{11}$, and $p^{*} \neq 1$. Therefore, if a capital market equilibrium exists, we must have $p^{*}>1$, in which case all type $(1,2)$ agents will supply type 2 capital, and claim that it is type 1. In equilibrium, some type 2 capital will be allocated to the type 2 production process and, as a result, the allocation is not IE and therefore not optimal, given propositions 3.1 and 3.2 Q.E.D.

Proposition 4.3 If $x_{11}<x_{22}$ a capital market equilibrium may not exist. Proof: Suppose $x_{11}<x_{22}$ and that :

$$
\left(x_{11}+x_{12}\right)^{-1}\left\{x_{11}\left[\pi_{1} r_{1}+\left(1-\pi_{1}\right) r_{2}\right]+x_{12}\left[\pi_{2} r_{1}+\left(1-\pi_{2}\right) r_{2}\right]\right\} \leq 1 \text { (4.1) }
$$

From the proof of proposition 4.2 , if an equilibrium exists, we will have $p^{*}>1$, and all type $(1,1)$ and type $(1,2)$ agents will supply alleged type 1 capital. In addition, some type $(2,2)$ agents may also claim their capital to be type 1 and sell it on the market. If an agent were to buy type 1 capital on the market and apply it to process 2 production, the return in terms of the period 3 consumption good is less than or equal to unity, given (4.3). Therefore, since $p^{\star}>1$, the return to selling type 2 capital for alleged 
type 1 capital and using this capital in either. production process is less than unity, the opportunity cost of type 2 capital. Therefore, an equilibrium does not exist.

Q.E.D.

In the case where $x_{11} \geq x_{22}$, there is no illiquidity problem. In equilibrium, the price of capital is such that it is not in the interest of those holding type 2 capital to sell it under the false claim that it is type 1. All agents know that what other agents claim to be type 1 capital is just that. However, if $x_{11}<x_{22}$, there exists no equilibrium in which type $(1,1)$ agents can credibly claim that the capital they are selling is in fact type 1 , since these agents will not be alive in pieriod 3 when the returns are realized. Agents are asymmetrically infolmed in period 1 concerning the expected return on capital, and assets are therefore illiquid. This illiquidity leads either to the non-existence of equilibrium or the non-optimality of equilibrium if it exists.

\section{Banking}

The illiquidity problem in a decentralized capital market arises due to an information externality; owners of type: 2 capital can free ride on owners of type 1 capital, and thus impair the trading process. In this section, we show how a collective, i.e. a "bank", can internalize this externality.

We define a bank to be a coalition of $n$ agents which forms in period zero and writes contracts contingent on the future state of the world. Since all agents are identical in period zero, we can think of the coalition in period one as being composed of $n$ agents who are each an independent draw from the period one population. Let $w_{i j}^{n}$ be a random variable which denotes the 
fraction of type $(i, j)$ agents in a coalition composed of $n$ agents. The problem the coalition solves, given $n$, is then the same problem solved by the coalition of the whole in section 3 , replacing $x$ by $w^{n}=\left(w_{11}^{n}, w_{12}^{n}, w_{21}^{n}\right.$, $\mathrm{w}_{22}^{\mathrm{n}}$ ). From propositions 3.1 and 3.2 , the level of expected utility attained by a representative agent in the coalition, denoted $U(n)$, is:

$$
U(n)=E\left[f\left(w^{n}\right)\right]
$$

where

$$
f\left(w^{n}\right)=\left\{\begin{array}{l}
\pi_{1} r_{1}+\left(1-\pi_{1}\right) r_{2}+\left(w_{12}^{n}+w_{22}^{n}\right)\left[1-\pi_{1} r_{1}-\left(1-\pi_{1}\right) r_{2}\right], w_{11}^{n} \leq w_{22}^{n} \\
\pi_{1} r_{1}+\left(1-\pi_{1}\right) r_{2}+\left(w_{11}^{n}+w_{12}^{n}\right)\left[1-\pi_{1} r_{1}-\left(1-\pi_{1}\right) r_{2}\right], w_{11}^{n} \geq w_{22}^{n}
\end{array}\right.
$$

Note that $f\left(w^{n}\right)$ is a concave function, as $w_{12}^{n}+w_{22}^{n}<w_{11}^{n}+w_{12}^{n}$ for $w_{11}^{n}>$ $\mathrm{w}_{22}^{\mathrm{n}}$.

Iterating expectations in (4.2), we get:

$$
U(n)=E\left\{E\left[f\left(W^{n}\right) \mid X\right]\right\}
$$

Since $W^{n} \rightarrow X$ as $n \rightarrow \infty$, we have:

$$
\begin{aligned}
\lim _{n \rightarrow \infty} U(n) & =E[f(x)] \\
& =E\left\{f\left(E\left[w^{m} \mid x\right]\right)\right\} \\
& <E\left\{E\left[f\left(w^{m}\right) \mid X\right]\right\} \\
& =U(m)
\end{aligned}
$$

for any finite $m$, where the inequality follows from the concavity of $f(\cdot)$ and the fact that, for finite $m, \operatorname{Pr}\left[w_{11}^{m}<w_{22}^{m} \mid x_{11} \geq x_{22}\right]>0$ and $\operatorname{Pr}\left[w_{11}^{m}>\right.$ $\left.w_{22}^{m} \mid x_{11} \leq x_{22}\right]>0$.

Banking coalitions will then choose to grow large $(n \rightarrow \infty)$, as this maximizes the expected utility of a representative member of the coalition. Though all agents are risk neutral, the expected payoff to a member of the coalition is a concave function of the fractions of agent types in the 
coalition. Coalition members are then effectively risk averse, and they can diversify against risk by forming a large coalition, so that the fraction in the coalition of each agent type converge:s to the corresponding fraction in the population.

We can then have an equilibrium with banking coalitions, in which $\mathbb{N}$ large coalitions form in period zero, each of which maximizes the expected utility of its members by offering optima.l allocations. Given proposition 3.2 , if $X=x$ in period one, an agent of type $(i, j)$ in a particular coalition, $k$, will be indifferent between the allocation offered by coalition $k$ and that offered by any other coalition. There will then be no incentive for agents to form alternative coalitions in period one.

An equilibrium with banking coalitions yields an optimal allocation. What we want to show is that such an equilibrium can be achieved through contracts which exhibit features of real world banking contracts. One such arrangement is the following. Each coalition agrees in period zero that in period one the bank will offer its members a choice of contracts. In exchange for one unit of type 2 capital, the bank offers a "type 2 " deposit contract. This contract gives its holder the right either to withdraw 1 unit of the consumption good in period 2, or to receive a stream of payments in periods 2 and 3 of $\left[\left(x_{22}-x_{11}\right) / x_{22}, x_{11}\left[\pi_{1} r_{1}+\left(1-\pi_{1}\right) r_{2}\right] / x_{22}\right]$ if $x_{11} \leq x_{22}$ or of $(0$, $\left.\pi_{1} r_{1}+\left(1-\pi_{2}\right) r_{2}\right)$ if $x_{11} \geq x_{22}$. The bank offers holders of type 1 capital a "type 1" deposit contract in exchange for a debt contract with the bank. This debt contract specifies that the borrower (the owner of the capital) make a payment to the bank of $\left[1-\pi_{2} r_{1}-\left(1-\pi_{1}\right) r_{2}\right] /\left(\pi_{1}-\pi_{2}\right)$ in period 3 or "default", in which case the bank receives the entire return on the agent's capital. The agent will then default only if the return on capital is $\mathbf{r}_{2}$. The type 1 deposit contract is a kind of compensating balance held with the 
bank, which may be withdrawn in period 2 in exchange for 1 unit of the period 2 consumption good. If held until time 3 , it gives a return of $\left\{\pi_{1}-\right.$ $\left.\pi_{2}\left\{\pi_{1} r_{1}+\left(1-\pi_{1}\right) r_{2}\right\}\right\} /\left(\pi_{1}-\pi_{2}\right)$. If a type 1 deposit is withdrawn in period 2 , the agent defaults on her debt and relinquishes title to her capital to the bank. There is a covenant attached to the debt which states that the borrower cannot allocate her capital to process 1 production.

If $x_{11} \leq x_{22}$, the bank allocates all type 1 capital to which it has claim to process 2 production, and all type 2 capital to process 1 production. If $x_{11} \geq x_{22}$, then all type 2 capital is allocated to process 1 production, $x_{11}-x_{22}$ units of type 1 capital are allocated to process 1 production, and the remaining type 1 capital is allocated to process 2 production. Requests for withdrawal are made simultaneously, and the bank allocates the available quantity of the consumption good equally in period 1 among those who request withdrawal. This amounts to introducing the possibility of suspension of convertibility, which will never be invoked, as it is never in the interest of type $(2, j)$ agents to withdraw.

The resulting allocation is: $c_{11}^{2}=c_{12}^{2}=1, c_{22}^{2}=1-x_{11} / x_{22}$ if $x_{11} \leq$ $x_{22}, c_{22}^{2}=0$ if $x_{11} \geq x_{22}, c_{22}^{3}=\left[x_{11} / x_{22}\right]\left[\pi_{1} r_{1}+\left(1-\pi_{1}\right) r_{2}\right]$ if $x_{11} \leq x_{22}$, $c_{22}^{3}=\pi_{1} r_{1}+\left(1-\pi_{1}\right) r_{2}$ if $x_{11} \geq x_{22}, c_{21}^{3}=\left\{\pi_{1}-\pi_{2}\left[\pi_{1} r_{1}+\left(1-\pi_{1}\right) r_{2}\right]\right\} /\left(\pi_{1}-\right.$ $\left.\pi_{2}\right), c_{211}=\left\{\pi_{1} r_{1}+\left(1-\pi_{1}\right) r_{2}-1\right\} /\left(\pi_{1}-\pi_{2}\right), c_{221}=c_{222}=c_{212}=0$. As is easily checked, this is an optimal allocation.

Banks in our model are like banks in the real world in the sense that they are "large" (they hold a diversified portfolio and write contracts with a large number of depositors), and write banking-type contracts. Their liabilities are deposit contracts which allow for early withdrawal, and their assets are the debt of other agents and the economy's primitive assets. If 
the bank holds an agent's debt, it also requires that the agent hold a compensating balance with the bank. Banks transform illiquid primitive assets into liquid assets, and therefore obviate the illiquidity problem which exists in decentralized capital markets.

\section{Bank Failures}

In period one states where $x_{11} \geq x_{22}$, all agents are indifferent between the equilibrium allocation with banking coalitions and the capital market equilibrium allocation. Indeed, one equilibrium arrangement which yields an allocation identical to that achieved with the banking contracts described in the previous section, is for some banking coalitions to dissolve (or "fail") in some period one states where $x_{11} \geq x_{22}$. Members of dissolved coalitions then proceed to trade capital in period one. Bank failure in some contingencies is then an optimal arrangement which all coalition members would agree to in period zero, and bank failures are systematic events in that they can occur only in some states of the world.

Empirical evidence (see Bernanke 1983, Friedman and Schwartz 1963 and Gorton 1985) for the U.S. suggests that periods when large numbers of bank failures occur tend to be periods when real output is low and the demand for liquidity is high. Our model is consistent with these stylized facts given some restrictions on the distribution function $F(\cdot)$. Suppose that the fraction of agents in the population endowed with type 1 capital is a constant, $\alpha$, where $0<\alpha<1$. Also, suppose that the fractions of type 1 and of type 2 agents endowed with type 1 capital are equal. That is, $(1-\alpha) \mathrm{x}_{11}$ $=\alpha x_{12}$ and $(1-\alpha) x_{21}=\alpha x_{22}$. We then have: 


$$
\begin{aligned}
& \mathrm{x}_{12}=[(1-\alpha) / \alpha] \mathrm{x}_{11} \\
& \mathrm{x}_{21}=\alpha-\mathrm{x}_{11} \\
& \mathrm{x}_{22}=1-\alpha-[(1-\alpha) / \alpha] \mathrm{x}_{11}
\end{aligned}
$$

Therefore, the population can be described in terms of a single random variable, $x_{11}$. Let $x_{11}$ be distributed according to the probability distribution function $G\left(x_{11}\right)$. Assume that, for any $x \in(0,1), 0<G(x)<1$.

Let $z$ denote a random variable which takes on a value of unity in states of the world where bank failures are possible, and is zero otherwise. That is, given (5.1),

$$
z= \begin{cases}1, & x_{11} \geq \alpha(1-\alpha) \\ 0, & x_{11}<\alpha(1-\alpha)\end{cases}
$$

The demand for liquidity can be measured in our model by the proportion of type $(1, j)$ agents in the population. With banking contracts, all of these agents will withdraw their deposits in period 2 . Letting $D$ be a random variable denoting the demand for liquidity, we have

$$
D=x_{11}+x_{12}=x_{11} / \alpha
$$

If we measure output, denoted $Y$, as the sum of period 2 and period 3 production of the consumption good (which equals aggregate consumption) we have, given (5.1),

$$
Y=\left\{\begin{array}{l}
X_{11} / \alpha+\left(1-x_{11} / \alpha\right)\left[\pi_{1} r_{1}+\left(1-\pi_{1}\right) r_{2}\right], \text { if } Z=1 \\
1-\alpha+\alpha\left[\pi_{1} r_{1}+\left(1-\pi_{1}\right) r_{2}\right], \text { if } z=0
\end{array}\right.
$$

We are interested in the association between output and the demand for liquidity on the one hand, and states of the world where bank failures are possible on the other. That is, we want to know how $Y$ and $D$ covary with $Z$. 
From (5.2), (5.3) and (5.4), we get:

$$
\begin{aligned}
& \operatorname{cov}(D, Z)=(1 / \alpha) G(\alpha /[1-\alpha])\left\{E\left[X_{11} \mid Z=1\right]-E\left[X_{11}\right]\right\}>0 \\
& \operatorname{cov}(Y, Z)=\left[1-\pi_{1} r_{1}-\left(1-\pi_{1}\right) r_{2}\right] \operatorname{cov}(D, Z)<0
\end{aligned}
$$

States of the world in which bank failures are a possibility tend to be states where the demand for liquidity is high and output is low. When some banks are failing, banks remaining in operation will tend to be experiencing larger than average deposit withdrawals. Observing this, we might conclude that a "bank panic" or a "bank run," is taking place, that this phenomenon is causing banks to fail, and that intervention is required. This conclusion is incorrect in our model, since the equilibrium allocation is optimal. Further, since bank failures are associated with low output, a causal link might be drawn from "panics" to real activity. Again, this inference would be incorrect.

\section{Summary and Conclusion}

In this paper, we have constructed a model in which an illiquidity problem arises. With decentralized trading in capital, an equilibrium does not exist in some states of the world, or if an equilibrium exists some agents have an incentive to make false claims in selling their capital. Buyers and sellers of capital are then asymetrically informed in equilibrium concerning the expected returns on capital, and resources are misallocated.

Banking institutions, which in our model are large multi-agent coalitions, are able to alleviate this illiquidity problem; i.e. they internalize an externality. Bank deposits provide for early withdrawal, banks hold debt, and agents who take out loans with banks hold compensating balances. 
Since in some states of the world agents are indifferent between the equilibrium allocation achieved with banking and the capital market equilibrium allocation, members of banking coalitions may agree ex ante that in some or all of these states the coalition will dissolve, and coalition members will simply trade capital. These bank failures are then systematically related to the state of the world, and they tend to occur when output is low and when the demand for liquidity is high. In a state of the world in which some banks are failing, banks remaining in operation will be experiencing larger than average withdrawals.

This model is novel in the banking literature in that: 1) a role for banking arises in a model where all agents are risk neutral; 2) bank failures are systematic events; 3 ) the existence of bank failures does not imply that government intervention is desirable. While states of the world in which banks fail have features which some might associate with "bank panics,." "bank runs," or "financial crises," such failures are by no means undesirable in our model. 


\section{Footnotes}

1

${ }^{1}$ Rolnick and Weber $(1984,1985)$, and to some extent King (1983), attempt to dispel the belief that the free banking era was a period of instability in banking.

${ }^{2}$ In Smith (1984), bank "instability" is in some sense systematic. However, as in Diamond and Dybvig, this generates a role for government intervention, though in the form of deposit interest rate ceilings rather than deposit insurance.

${ }^{3}$ This allocation is supported by a banking system in the absence of bank runs.

${ }^{4}$ The Boyd and Prescott framework has only two agent types. Therefore, in our model we add (3.14). 


\section{References}

Bernanke, B., 1983, "Nonmonetary Effects of the Financial Crisis in the Propagation of the Great Depression," American Economic Review 73, No. $3,257-76$.

Boyd, J. and E. Prescott, 1985, "Financial Intermediary-Coalitions," Federal Reserve Bank of Minneapolis Research Department working paper \#272. Diamond, D. and P. Dybvig, 1983, "Bank Runs, Deposit Insurance, and Liquidity," Journal of Political Economy 91, No. 3, 401-19.

Freeman, S., 1985, "Bank Runs and the Provision of Liquidity," manuscript, Boston College and University of Western Ontario.

Friedman, M., 1960, A Program for Monetary Stability, Fordham University Press, New York. , and A. Schwartz, 1963, A Monetary History of the United States 1867-1960, Princeton University Press, Princeton, N.J.

Gorton, G., 1985, "Banking Panics and Business Cycles," manuscript, the Wharton School, University of Pennsylvania.

Haubrich, J. and R. King, 1983, "Banking and Insurance," manuscript, University of Rochester and NBER.

Harris, M. and R. Townsend, 1981, "Resource Allocation Under Asymmetric Information," Econometrica 49, 33-64.

Jacklin, C., 1983, "Information and the Choice Between Deposit and Equity Contracts," manuscript, Graduate School of Business, Stanford University. , 1984, "Demand Deposits, Trading Restrictions, and Risk Sharing," working paper \#139, Graduate School of Business, University of Chicago. 
King, R., 1983, "On the Economics of Private Money," Journal of Monetary Economics 12 , No. $1,127-58$.

Rolnick, A., and W. Weber, 1984, "The Causes of Free Bank Failures: A Detailed Examination," Journal of Monetary Economics, 14, No. 3, 267-92. , 1985, "Inherent Instability In Banking: The Free Banking Experience," Working Paper, Federal Reserve Bank of Minneapolis. Smith, B., 1984, "Private Information, Deposit Interest Rates, and the 'Stability' of the Banking System," Journal of Monetary Economics 14 , No. $3,293-318$.

Tobin, J., 1965, "The Theory of Portfolio Selection" in The Theory of Interest Rates, F. Hahn and F. Brechling eds., McMillan, London. Waldo, D., 1985, "Bank Runs, the Deposit-Currency Ratio and the Interest Rate," Journal of Monetary Economics 15, No. 3, 269-78. 
$8401 \mathrm{C}$ Harrison, Glenn W. and Manning, Richard. BEST APPROXIMATE AGGREGATION OF INPUT-OUTPUT SYSTEMS.

8402C Parkin, Michael. CORE INFLATION: A REVIEW ESSAY.

8403C Blomqvist, Ảke, and McMahon, Gary. SIMULATING COMMERICAL POLICY IN A SMALL, OPEN DUAL ECONOMY WITH URBAN UNEMPLOYMENT: A GENERAL EQUILIBRIUM APPROACH.

8404C Wonnacott, Ronald. THE THEORY OF TRADE DISCRIMINATION: THE MIRROR IMAGE OF VINERIAN PREFERENCE THEORY?

8405C Whalley, John. IMPACTS OF A 50\% TARIFF REDUCTION IN AN EIGHT-REGION GLOBAL TRADE MODEL.

8406C Harrison, Glenn w. A GENERAL EQUILIBRIUM ANALYSIS OF TARIFP REDUCTIONS.

8407C Horstmann, Ignatius and Markusen, James R. STRATEGIC INVESTMENTS AND THE DEVELOPMENT OF MULTINATIONALS.

8408C Gregory, Allan W. and McCurdy, Thomas H. TESTING THE UNBIASEDNESS HYPOTHESIS IN THE FORINARD FOREIGN EXCHANGE MARKET: A SPECIFICATION ANALYSIS.

8409C Jones, Ronald H. and Klerzkowsk1, Henryk. NEIGHBORHOOD PRODUCTION STRUCTURES WITH APPLICATIONS TO THE THEORY OF INTERNATIONAL TRADE.

8410C Weller, Paul and Yano, Makoto. THE ROLE OF FUTURES MARKETS IN INTERNATIONAL TRADE: A GENERAL EỌUILIBRIUM APPROACH.

8411C Brecher, Richard A, and Bhagwat1, Jagdish N. VOLUNTARY EXPORT RESTRICTIONS VERSUS IMPORT RESTRICTIONS: A WELFARE-THEORETIC COMPARISON.

8412C Ethier, Wilfred J. ILLEGAL IMMIGRATION.

8413C Eaton, Jonathon and Gene M. Grossman. OPTIMAL TRADE AND INDUSTRIAL POLICY UNDER OLIGOPOLY.

8414C Hooton, Ian. PREFERENTIAL TRADING AGREEMENTS - A 3xn MODEL.

8415C Parkin, Michael. DISCRIMINATJNG BETWEEN KEYNESIAN AND

CLASSICAL TIIEORIES OF THE BUSINESS CYCLE; JAPAN 1967-1982

8416C Deardorff, Alan V. FIRless FIRwoes: HOW PREFERENCES CAN INTERFERE WITH THE THEOREMS OF INTERNATIONAL TRADE.

8417C Greenwood, Jeremy. NONTRADED GOODS, THE TRADE BALANCE, AND THE BALANCE OF PAYRENTS. 
8418C Blomqvist, Ake and Sharif Mohammad. CONTROLS, CORRUPTION, AND COMPETITIVE RENT-SEEKIN, IN LDCs.

8419C Grossman, Herschel I. POLICY, RATIONAL EXPECTATIONS, AND POSITIVE ECONOMIC ANALYSIS.

8420C Garber, Peter M. and Robert G. King. DEEP STRUCTURAL EXCAVATION? A CRITIOUE OF EULER EQUATION METHODS.

$8421 \mathrm{C}$ Barro, Robert J. THE BEHAVIOR OF U.S. DEFICITS.

8422C Persson, Torsten and Lars E.0. Svensson. INTERNATIONAL BORROWING AND TIME-CONSISTENT FISCAL POLICY.

8423C Obstfeld Maurice. CAPITAL CONTROLS, THE DUAL EXCHANGE RATE, AND DEVALUATION.

8424C Kuhn, Peter. UNION PRODUCTIVITY EFFECTS AND ECONOMIC EFFICIENCY.

8425C Hamilton, Bob and John Whalley. TAX TREATMENT OF HOUSING IN A DYNAMIC SEỌUENCED GENERAL EỌUILIBRIUM MODEL.

$\because 426 \mathrm{C}$ Hamilton, Bob, Sharif Mohammad, and John Whalley. RENT SEEKING AND THE NORTH-SOUTH TERMS OF TRADE.

8427C Adams, Charles and Jeremy Greenwood. DUAL EXCHANGE RATE SYSTEMS AND CAPITAL CONTROLS: AN INVESTIGATION.

8428 Loh, Choon Cheong and Michael $R$. Veall. A NOTE ON SOCIAL SECURITY AND PRIVATE SAVINGS IN SINGAPORE.

8429 Whalley, John. REGRESSION OR PROGRESSION: THE TAXING OUESTION OF INCIDENCE ANALYSIS.

3430 Kuhn, Peter. WAGES, EFFORT, AND INCENTIVE-COMPATIBILITY IN LIFE-CYCLE EMPLOYMENT CONTRACTS.

8431 Greenwood, Jeremy and Kent P. Kimbrough. AN INVESTIGATION IN THE THEORY OF FOREISN EXCHANGE CONTROLS.

8432 Greenwood, Jeremy and Kent P. Kimbrough. CAPITAL CONTROLS AND THE INTERNATIONAL TRANSMISSION OF FISCAL POLICY.

8433 : Nguyen, Trien Trien and John Whalley. EỌUILIBRIUM UNDER PRICE CONTROLS WITH ENDOGENOUS TRANSACTIONS COSTS.

8434 Adams, Charles and Russell S. Boyer. EFFICIENCY AND A SIMPLE MODEL OF EXCHANGE RATE DETERMINATION. 
8435 Kuhn, Peter. UNIONS, ENTREPRENEURSHIP, AND EFFICIENCY.

8436 Hercowitz, Zv1 and Efraim Sadka. ON OPTTMAL CURRENCY. SUBSTITUTION POLICY AND PUBLIC PINANCE.

8437 Lenjosck, Gordon and John Whalley. POLICY EVALUATION IN A SMALL OPEN PRICE TAKING ECONOMY: CANADIAN ENERGY POLICIES.

8438 Aschauer, David and Jeremy Greenwood. MACROECONOMIC EFFECTS OF FISCAL POLICY.

8439C Hercowitz, ZVI. ON THE DETERMINATION OF THE EXTERNAL DEBT: THE CASE OF ISRAEL.

8440C Stern, Robert M. GLOBAL DIMENSIONS AND DETERMINANTS OF INTERNATIONAL TRADE AND INVESTMENT IN SERVICES.

$8441 \mathrm{C}$ Deardorff, Alan V. COMPARATIVE ADVANTAGE AND INTERNATIONAL TRADE AND INVESTMENT IN SERVICES.

8442C Daly, Donald J. TECHNOLOGY TRANSFER AND CANADA'S COMPETITIVE PERFORMANCE.

8443C Grey, Rodney de C. NEGOTIATING ABOUT TRADE AND INVESTMENT IN SERVICES.

8444C Grossman, Gene M. and Carl Shapiro. NORMATIVE ISSUES RAISED BY INTERNATIONAL TRADE IN TECHNOLOGY SERVICES.

8445C Chant, John F. THE CANADIAN TREATMENT OF FOREIGN BANKS: A CASE STUDY IN THE WORKINGS OF THE NATIONAL TREATMENT APPROACH.

8446C Aronson, Jonathan D. and Peter F. Cowhey. COMPUTER, DATA PROCESSING, AND COMMUNICATION SERVICES.

8447C Feketekuty, Geza. NEGOTIATING STRATEGIES FOR LIBERALIZING TRADE AND INVESTMENT IN SERVICES.

8448C Harrison, Glenn, W. and E.E. Rutstrom. THE EFFECT OF MANUFACTURING SECTOR PROTECTION ON ASEAN AND AUSTRALIA: A GENERAL ENUILIBRIUM ANALYSIS. 
8501C Greenwood, Jeremy and Kent P. Kimbrough. FOREIGN EXCHANGE CONTROLS IN A BLACK MARKET ECONOMY.

8502C Horstmann, Ignatius and James R. Markusen. UP YOUR AVERAGE COST CURVE: INEFFICIENT ENTRY AND THE NEW PROTECTIONISM.

8503C Gregory, Allan W. TESTING INTEREST RATE PARITY AND RATIONAL EXPECTATIONS FOR CANADA AND THE UNITED STATES.

8504C Kuhn, Peter and Ian Hooton. INTERNATIONAL FACTOR MOVEMENTS IN THE PRESENCE OF A FIXED FACTOR.

8505C Wong, Kar-ylu. GAINS FROM GOODS TRADE AND FACTOR MOBILITY.

8506C Weller, Paul and Makoto Yano. FUTURES MARKETS, REAL INCOME, AND SPOT PRICE VARIABILITY: A GENERAL EOUUILIBRIUM APPROACH.

8507C Dlewert, H.E. THE EFFECTS OF AN INNOVATION: A TRADE THEORY APPROACH.

8508C Ethier, Wilfred J. POREIGN DIRECT INVESTMENT AND THE MULTINATIONAL FIRM.

8509C Dinopoulos, Ellas. INSIDE THE BLACK BOX: (IN)TANGIBLE ASSETS, INTRA-INDUSTRY INVESTMENT AND TRADE.

8510C Jones, Richard, John Whalley, and Randall Higle. REGIONAL IMPACTS OF TARIFFS IN CANADA: PRELIMINARY RESULTS FROM A SMALL DIMENSIONAL NUMERICAL GENERAL EOUUILIBRIUM MODEL.

8511C Whalley, John. HIDDEN CHALLENGES IN RECENT APPLIED GENERAL EQUIL IBRIUM EXERCISES.

8512C Smith, Bruce. SOME COLONIAL EVIDENCE ON TWO THEORIES OF MONEY: MARVLAND AND THE CAROLINAS.

3513C Grossman, S.J., A. Melino, and R.J. Shiller. ESTIMATING THE CONTINUOUS TIME CONSUMPTION BASED ASSET PRICING MODEL.

8514C Romer, Paul R. TAX EFFECTS AND TRANSACTION COSTS FOR SHORT TERM MARKET DISCOUNT BONDS.

8515C McCallum, Bennett T. ON CONSEOUUENCES AND CRITJCISMS OF MONETARY TARGETING.

8516C Dinopoulos, Elias and Ian Wooton. A NORTH-SOUTH MODEL OF INTERNATIONAL JUSTICE.

8517C Huffman, Gregory W. A DYNAMIC EQUILIBRIUM MODEL OF ASSET PRICES AND TRANSACTION VOLUME.

8518C Huffman, Gregory W. AN ALTERNATIVE VIEW OF OPTIMAL SEIGNIORAGE.

8519C Huffman, Gregory W. ASSET PRICING WITH HETERGENEOUS ASSETS. 
8520C Hercowitz, Zvi. THE REAL INTEREST RATE AND AGGREGATE SUPPLY.

8521C Davies, James and Michael Hoy. COMPARING INCOME DISTRIBUTIONS UNDER AVERSION TO DOWNSIDE INEQUALITY.

8522C Nguyen, Trien T. and John Whalley. COEXISTENCE OF EQUILIBRIA ON BLACK AND WHITE MARKETS.

8523C Clarete, Ramon and John Whalley. INTERACTIONS BETWEEN TRADE POLICIES AND DOMESTIC DISTORTIONS: THE PHILIPPINE CASE.

8524C Hamilton, Bob, Sharif Mohammad, and John Whalley. APPLIED GENERAL EQUILIBRIUM ANALYSIS AND PERSPECTIVES ON GROWTH PERFORMANCE.

8525C Huffman, Gregory $W$. THE LAGGED EFFECTS OF POLICY ON THE PRICE LEVEL.

8526C Laidler, David. FISCAL DEFICITS AND INTERNATIONAL MONETARY INSTITUTIONS.

8527C Goodfriend, Marvin. MONETARY MYSTIQUE: SECRECY AND CENTRAL BANKING.

8528C Nguyen, Trien $T$. and John Whalley. GENERAL EQUILIBRIUM ANALYSIS OF PRICE CONTROLS A TWO-SECTOR COMPUTATIONAL APPROACH.

8529C Heckman, James J. and V. Joseph Hotz. AN INVESTIGATION OF THE LABOR MARKET EARNINGS OF PANAMANIAN MALES: EVALUATING SOURCES OF INEQUALITY.

8530C Greenwood, Jeremy and Gregory W. Huffman. A DYNAMIC EQUILIBRIUM MODEL OF INFLATION AND UNEMPLOYMENT.

8531C Freeman, Scott. INSIDE MONEY, MONETARY CONTRACTIONS, AND WELFARE.

8532C Paderanga, Cayetano Jr. and Ian Wooton. A POSITIVE VIEW OF INFANT INDUSTRIES.

$8533 \mathrm{C}$ St-Hilaire, France and John Whalley. A MICROCONSISTENT DATA SET FOR CANADA FOR USE IN REGIONAL GENERAL EQUILIBRIUM POLICY ANALYSIS.

8534C Whalley, John. OPERATIONALIZING WALRAS: EXPERIENCE WITH RECENT APPLIED GENERAL EQUILIBRIUM TAX MODELS.

8535C Melvin, James R. THE GENERAL NON-EQUIVALENCE OF TARIFFS AND IMPORT QUOTAS. 
8601C Greenwood, Jeremy and R. Preston McAfee. EXTERNALITIES AND ASYMMETRIC INFORMATION.

8602C Dinopoulos, Elias and Mordecha1 E. Kreinin. IMPORT OQUOTAS AND VERS: A COMPARATIVE ANALYSIS IN A THREE-COUNTRY FRAMEWORK.

$8603 \mathrm{C}$ Clarete, Ramon and John Whalley. COMPARING THE MARGINAL WELFARE COSTS OF COMMODITY AND TRADE TAXES.

8604C Wigle, Randy. CANADIAN TRADE LIBERALIZATION: SCALE ECONOMIES IN A GLOBAL CONTEXT.

8605C Parkin, Michael. DOMESTIC MONETARY INSTITUTIONS AND FISCAL DEFICITS.

8606C Dinopoulos, Elias and Ian Wooton. INTERNATIONAL TRADE AND THE ACOUUISITION OF SKILLS.

8607C Kawasaki, Seiichi and John McMillan. THE DESIGN OF CONTRACTS: EVIDENCE FROM JAPANESE SUBCONTRACTING.

8608C Williamson, Stephen D. LIQUIDITY, BANKING, AND BANK FAILURES. 